The Isolation and Characterization of Phosphate Solubilizing Bacteria from the Onion Rhizosphere and Their Effect on Onion Growth

\author{
İdris BEKTAŞ ${ }^{\varnothing}$, Mustafa KÜSEK ${ }^{2}$ \\ University, Faculty of Agriculture, Department of Plant Protection, Kahramanmaras \\ ${ }^{1} \mathrm{https}: / /$ orcid.org/0000-0001-7409-4837, ${ }^{2} \mathrm{https}: / /$ orcid.org/0000-0002-6320-5869 \\ 凶: idris.bektas@amasya.edu.tr
}

${ }^{1}$ Amasya University, Suluova Vocational School, Department of Plant and Animal Production, Amasya, ${ }^{2}$ Kahramanmaras Sutcu Imam

\begin{abstract}
In this study 269 phosphate solubilizing bacteria (PSB) strains were isolated from onions rhizosphere. The 15 most efficient PSB were selected. Based on BIOLOG profiling and the LOPAT test system, the strains were identified as Enterobacter cloacae (7), Yersinia intermedia, Pantoea agglomerans, Bacillus subtilis(2), Bacillus pumilius, Lysinibacillus sphaericus and Bacillus atrophaeus(2). The PSB effect on onion growth was investigated under greenhouse conditions. These PSB increased plant height (11.7 to $38.8 \%)$, the number of leaves ( 3 to $70 \%$ ), the bulb diameter (6.4 to $64.5 \%$ ), the average root length (2.6 to $44.7 \%)$, the fresh weight of the bulb (2.9 to $34.1 \%)$ and the dry weight of the bulb (1.5 to $40.6 \%$ ) when compared to the negative control. Among these strains the most effective inoculants were the highest $\mathrm{P}$ solubizing E.cloacae EB-14 and E. cloacae OB-169 strains, which significantly increased all parameters compared to the commercial plant activator ISR 2000. These results demonstrated the potential use of these PSB as inoculants for onion growth.
\end{abstract}

\section{Research Article}

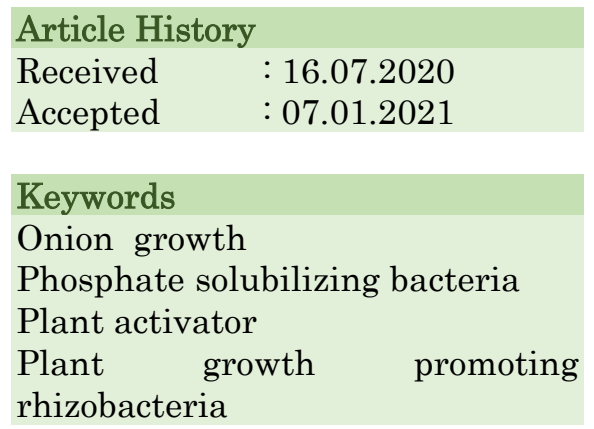

\title{
Soğan (Allium cepa L.) Rizosferindeki Fosfat Çözen Bakterilerin İzolasyonu, Karakterisasyonu ve Soğan Gelişimi Üzerine Etkisi
}
ÖZET
Bu çalışmada 269 fosfat çözen bakteri(PSB) izolatı soğan rizosfer bölgesinden izole edilmiştir. İzolatlar arasından en fazla fosfat çözen 15 bakteri seçilmiştir. BIOLOG test profiline ve LOPAT test sistemine göre seçilen izolatlar Enterobacter cloacae(7), Yersinia intermedia, Pantoea agglomerans, Bacillus subtilis(2), Bacillus pumilius, Lysinibacillus sphaericus ve Bacillus atrophaeus(2) olarak tanılanmıştır. $\mathrm{Bu}$ izolatların soğan gelişi üzerine etkisi sera koşullarında incelenmiştir. Seçilen bu izolatlar kontrole göre, bitki boyunu \%11.7-38.8, yaprak sayısını \%3-70, yumru çapını \%6.4-64.5, ortalama kök uzunluğunu \%2.6-44.7, soğan yumru yaş ağırlığını \%2.9-34.1 ve soğan yumru kuru ağırlığını \%1.5-40.6 arasında artırdıkları belirlenmiştir. P çözen izolatlar arasındaki E. cloacae EB- 14 ve E. cloacae OB-169 tüm paramertreleri ticari bir bitki aktivatörü ürün olan ISR 2000 den istatistiki olarak daha fazla artırarak en etkili izolatlar olmuşlardır. Bu sonuçlar göstermiştir ki PSB'ler soğan gelişimi için potansiyel bir inokulant olarak kullanılabilir.

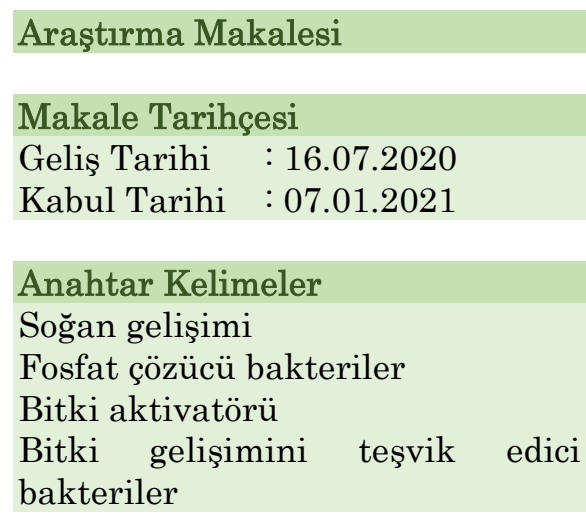
To Cite: $\quad$ Bektaş İ, Küsek M 2021. The Isolation and Characterization of Phosphate Solubilizing Bacteria from the Onion Rhizosphere and Their Effect on Onion Growth. KSU J. Agric Nat 24 (5): 1084-1092. DOI: 10.18016/ ksutarimdoga.vi.811324.

\section{INTRODUCTION}

Onion (Allium cepa L.), a member of Amaryllidaceae family, is one of the most economically important vegetables in all parts of the world due to its nutritional and medicinal values, including anticancer, anti-cholesterol, anti-inflammatory and antioxidant properties (Nasri et al., 2012). At the same time, onion contains important amounts of mineral salts, sulphur and potassium salts, and various trace elements, vitamins (B1, B2, C, E, K), carotene (provitamin A), glycosides, etheric oils and plant 
hormones like insulin (Slimestad et al., 2007). Onion's root system has little absorbent and penetrating properties, there must be an abundant source of accessible nutrients in the root area. The required amount of easily accessible nutritients in the soil for an optimal yield of onion growth is 60 to $140 \mathrm{~kg}$ of $\mathrm{N}$, 60 to $120 \mathrm{~kg}$ of $\mathrm{P}_{2} \mathrm{O}_{5}$ and 60 to $180 \mathrm{~kg}$ of $\mathrm{K}_{2} \mathrm{O}$ per hectare (Kumar et al., 2001).

Chemical fertilizers are usually used to provide major nutrients to the soil plant system around the world. But, the price and ecological problems of fertilizers are the most significant problem in today's agriculture, and there is a requirement to find different methods that can improve crop yields, maintain ecological safety and prevention, while protecting long-term environmental stability in the agro-ecosystem (Majeed et al., 2015). Plant growth-promoting rhizobacteria (PGPR) are beneficial native and soil bacteria that colonize the plant rhizosphere (Aktan and Soylu, 2020). PGPR inoculation of seeds or crops increases the growth and yield of plants (Kumar et al., 2014). The mechanisms of PGPR that fix nitrogen from the atmosphere and supply the plant can be through the synthesis of phytohormones and also phosphorous can be made available to plants by the solubilization of inorganic phosphate and by mineralization of organic phosphate (Zhang et al., 2018). Phosphorus (P) is one of the significant major elements for biological growth and improvement (Bhat et al., 2017), but the concentration of soluble $\mathrm{P}$ in soil is generally very low because of different chemical reactions, especially in arid and semi-arid soils (Sharma et al., 2013). The largest reserves of phosphorus are rocks and other deposits like basic apatites and another primary elements (Lompo et al., 2018). Agricultural lands hold major reserves of phosphorus, a important part of which has accumulated as a result of the regular use of P fertilizers (Cruz-Paredes et al., 2017). Different researchers have investigated the ability of various bacterial types to solubilize otherwise insoluble inorganic phosphate compounds, like rock phosphate, hydroxyapatite, dicalcium phosphate and tricalcium phosphate (Khan et al., 2010).

The number of phosphate solubilizing bacteria (PSB) is not adequately high enough to compete with different bacteria usually situated in the rhizosphere (Duman and Soylu, 2019). Therefore, the volume of $\mathrm{P}$ liberated by them is usually not enough for a significant rise in plant growth. Thus, inoculation of plants with a PSB at a very higher concentration than can generally be found in the soil is required to take advantage of the characteristics of phosphate solubilization for plant crop increases (Rodriguez and Fraga, 1999). In this study, potential PSB were isolated from the rhizosphere of healthy onion plants growing in surveyed fields located in Amasya. All strains were tested for their in vitro $\mathrm{P}$ solubilizing potential using broth and solid National Botanical Research Institute Phosphate (NBRIP) containing tricalcium phosphate (TCP). The 15 highest phosphorus solubilizing bacterial strains were identified with biochemical tests and the BIOLOG GEN III system. In addition to identification studies, the strains were tested for their ability to promote growth under greenhouse conditions in onion plants. The effects of PGPR strains on plant-growth parameters were statistically compared to each other and ISR 2000 was used as a commercial plant activator.

\section{MATERIALS and METHODS}

\section{Isolation and Identification of PSB}

Soil samples were collected from the onion plant's rhizosphere from certain fields of Amasya in Turkey. The soil samples were placed on blotting paper and kept at $25^{\circ} \mathrm{C}$. From that dry soil, 10 grams were put in $250 \mathrm{ml}$ erlenmeyer flasks and $90 \mathrm{ml}$ of sterile pure physiological saline solution $(0.85 \%)$ was added to them. The erlenmeyers were shaken for 30 minutes in a shaker. Half a milliliter of suspension and $4.5 \mathrm{ml}$ of pure physiological saline solution was added to $10 \mathrm{ml}$ tube vials and shaken for 1 minute. Up to $10^{-7}$ dilution was achieved by a serial dilution method. An $100 \mu \mathrm{l}$ aliquot of this suspension was spread on to plates with solid NBRIP growth medium containing $\left(\mathrm{g} \mathrm{l}^{-1}\right): 10 \mathrm{~g}$ of glucose, $5 \mathrm{~g}$ of $\mathrm{Ca}_{3}(\mathrm{PO} 4)_{2}, 5 \mathrm{~g}$ of $\mathrm{MgCl}_{2} \cdot 6 \mathrm{H}_{2} \mathrm{O}, 0.25 \mathrm{~g}$ of $\mathrm{MgSO}_{4} \cdot 7 \mathrm{H}_{2} \mathrm{O}, 0.2 \mathrm{~g}$ of $\mathrm{KCl}, 0.1 \mathrm{~g}$ of $\left(\mathrm{NH}_{4}\right)_{2} \mathrm{SO}_{4}$ and $20 \mathrm{~g}$ of agar (Nautiyal, 1999). The dishes were incubated at $25^{\circ} \mathrm{C}$ for 1 week and $\mathrm{P}$ solubilizing strain colonies with a clear zone were consired positive for phosphate solubilization. The index of phosphate solubilization was determined by using the following formula (Premono et al., 1996).

\section{SI $($ Solubilisation Index $)=$ total diameter $($ colony + halo zone)/colony diameter}

At the same time these phosphate solubilizing strains were tested for their in vitro phosphate solubilizing features in NBRIP broth medium $\left(\left(\mathrm{g} \mathrm{l}^{-1}\right): 10.0 \mathrm{~g}\right.$ of glucose, $10.0 \mathrm{~g}$ of tricalcium phosphate (TCP), $5.0 \mathrm{~g}$ of $\mathrm{MgCl}_{2} .6 \mathrm{H}_{2} \mathrm{O}, 0.25 \mathrm{~g}$ of $\mathrm{MgSO}_{4} .7 \mathrm{H}_{2} \mathrm{O}, 0.2 \mathrm{~g}$ of $\mathrm{KCl}, 0.1 \mathrm{~g}$ of $\left.\left(\mathrm{NH}_{4}\right)_{2} \mathrm{SO}_{4}\right)$. The quantitative measurement of phosphate solubilization was carried out using $15 \mathrm{ml}$ test tubes containing $10 \mathrm{ml}$ of NBRIP growth medium freshly inoculated with $0.1 \mathrm{ml}$ of each strain of PSB. Incubation was done at $27^{\circ} \mathrm{C}$ in an incubator shaker at $125 \mathrm{rpm}$ for 7 days. The tubes were then centrifuged at $10.000 \mathrm{rpm}$ for 15 minutes and the supernatant of each culture was analyzed for phosphate concentration in ppm by using the by Barton (1948) method. Among the phosphate solubilizing strains, thirteen strains with the highest $\mathrm{P}$ solubizing potential in NBRIP broth medium and two strains with the highest SI were selected for use in vivo pot experiments. The 15 strains were identified by using the BIOLOG GEN III 
(BIOLOG 21124 Cabot Blvd.Hayward, CA 94545) identification system.

\section{Pathogenicity Test and Biochemical Features of PSB}

The pathogenicity tests were performed according to by Moragrega et al. (2003), with in vivo methods. PSB strains grown in Nutrient broth(NB) at $27^{\circ} \mathrm{C}$ for 72 hours were centrifuged for $5 \mathrm{~min}$. at $10.000 \mathrm{rpm}$ and the pellet was adjusted in sterile distilled water to a concentration of approximately $1 \times 10^{6} \mathrm{CFU} \mathrm{ml}^{-1}$. Bacterial suspensions of about $20 \mu \mathrm{l}$ were injected into the onion bulb stems using a sterile needle. Sterile water was used as a negative control and Pectobacterium chrysanthemi F-161 which is the agent of soft rot for onion was used as a positive control (Dadaşoğlu and Kotan, 2017). In both pathogenicity tests, all treatments were carried out in triplicate. Onion materials were kept at $27^{\circ} \mathrm{C}$ in a mist chamber and disease development was assessed up to 1 weeks. The selected 15 PSB bacterial strains were identified by biochemical tests including LOPAT tests (levan production, oxidase reaction, potato soft rot, arginine dihydrolase, tobacco hypersensitivity) according to methods previously described by Schaad et al. (2001).

\section{Preparing the Soil and Pot Experiment}

Soils for the experiment were collected in from the Amasya region. Soil samples were taken from a depth of 30 to $35 \mathrm{~cm}$ deep from barren land for phosphorus analysis before the study. Phosphorus analysis of the soil samples was done to determine the amount of soluble phosphorus in the soil. The pot experiment soil was prepared to the phosphorus-poor soil with 5\% rock phosphate, manure and sand (vol/vol 1:1:1, pH of 7.0) . The onion seeds were inoculated with fifteen high ratio PSB strains. The PSB strains were grown in $15 \mathrm{ml}$ tubes in nutrient broth (NB) on a rotating shaker (125 rpm) for 24 hours at $27^{\circ} \mathrm{C}$. The tubes were centrifuged at $10.000 \mathrm{rpm}$ and the supernatant was removed from the precipitate. The density of the PSB strains was adjusted to 0.3 absorbance at a wavelength of $600 \mathrm{~nm}$ with sterile physiological saline solution using a spectrophotometer to $10^{8}$ CFU(Colony Forming Unit)/mL. One to two drops of Tween 80 were added to the suspension to prevent the clustering of the bacteria and to ensure a homogeneous distribution. The PSB strains were used as onion seed treatments. The onion seeds were surface sterilized with an $0.1 \%$ solution of $\mathrm{NaClO}$ (sodium hypochlorite) for 2.5 minutes and rinsed completely with sterile water and air dried on sterile filter paper. The onion seeds $(5 \mathrm{~g})$ were inoculated while keeping in $50 \mathrm{ml}$ of each PSB strains for 12 hours (Ramamoorthy et al., 2002). While negative control experiment seeds were not inoculated, the positive control was inoculated with commercial plant activator ISR 2000 (Lactobacillus acidophilus + yeast extract + plant extract + benzoic acid). For each treatment, five replicates from one onion plant were grown in $20 \mathrm{~cm}$ diameter pots. The study was done in a greenhouse with an average temperature of $27^{\circ} \mathrm{C}$, humidity of about $55 \%$ and a photoperiod of about 12 to 13 hours of daylight. Six months later, the onions were collected from the pots and the bulb diameter, root length, plant height, number of leaves, and the weights of fresh and dry onion bulb were determined for each application.

\section{Statistical Analysis}

The quantitative data on onion growth were statistically compared to each other with analysis of variance using the SPSS 20 (Statistical Package for Social Sciences) software program. Treatment means were compared using the Duncan's Multiple Range Test at $\mathrm{p} \leq 0.05$.

\section{RESULTS and DISCUSSION}

\section{Isolation and Identification of PSB}

For use in research, 269 potential PSB strains were obtained from a healthy onion rhizosphere region. In vitro studies of the $\mathrm{P}$ solubilization index of $\mathrm{PSB}$ strains are defined to be between 1.3 to 5.1 on NBRIP agar medium. However, in the NBRIP broth medium a rate of 19.3 to $382.5 \mu \mathrm{g} \mathrm{ml}^{-1}$ was detected.Among the PSB strains, fifteen PSB strains having the highest $\mathrm{P}$ solubizing potential strains (three on NBRIP agar medium and twelve on NBRIP broth medium) were selected to use for the in vivo pot experiments. The 15 bacterial strains were identified as Enterobacter cloacae(7), Bacillus atrophaeus(2), Bacillus subtilis(2), Yersinia intermedia, Bacillus pumilus, Lysinibacillus sphaericus and Pantoea agglomerans by using LOPAT tests, Gram tests and BIOLOG profiling (Table 1).

\section{The Pathogenicity Test and Biochemical Features of PSB}

The PSB bacterial strains isolated from the onion rhizosphere exhibited different pathogenicity results on sensitive Kantartopu onion accessions. The Pectobacterium chrysanthemi F-161 reference strain caused typical onion rot symptoms on the onion bulbs (watery tissue, necrotic lesions) and was the most pathogenic of the strains tested. In the pathogenicity tests, all selected PSB strains showed negative pathogenicity on onion bulbs. The selected PSB bacterial strains that were isolated from the onion rhizosphere and classified by the LOPAT tests exhibited diverse results. As a result of the lopat test,seven strains of Enterobacter cloacae, Pantoea agglomerans and Yersinia intermedia strains resulted in LOPAT $(+,-,-,+,-)$, while two strains of Bacillus subtilis, Bacillus pumilus, Lysinibacillus sphaericus and two strains of Bacillus atrophaeus strains resulted in LOPAT $(-,-,-,+,-)$. All Enterobacter cloacae and 
Pantoea agglomerans strains were Gram negative except for Bacillus sp. strain which were Gram positive. All PSB were oxidase, potato soft rot and tobacco hypersensitivity negative, at the same time, all PSB showed arginine dihydrolase positive characteristics. The results of the levan production test showed that Enterobacter cloacae and Pantoea agglomerans were negative while Bacillus sp. was positive (Table1).

Table1.BIOLOG profiling andLOPAT tests analyses of selected P solubilizing PGPR strains Çizelge1. Seçilen P çözücü PGPR izolatlarının BIOLOG test profili ve LOPAT test analazi

\begin{tabular}{|c|c|c|c|c|c|c|c|c|c|}
\hline \multirow{2}{*}{$\begin{array}{c}\text { PGPR } \\
\text { strains } \\
(P G P R \\
\text { izolatları) }\end{array}$} & \multirow{2}{*}{$\begin{array}{l}\text { BIOLOG profiling } \\
\text { (BIOLOG profili) }\end{array}$} & \multirow{2}{*}{$\begin{array}{c}\mathrm{P} \text { solubising } \\
(P \text { çözme } \\
\text { potansiyeli }) \mathrm{ppm}\end{array}$} & \multirow[t]{2}{*}{ PSI } & \multirow{2}{*}{$\begin{array}{l}\text { Gram test } \\
\text { (Gram } \\
\text { testi) }\end{array}$} & \multicolumn{5}{|c|}{$\begin{array}{c}\text { LOPAT tests results (LOPAT test } \\
\text { sonucu) }\end{array}$} \\
\hline & & & & & $\mathrm{L}$ & $\mathrm{O}$ & $\mathrm{P}$ & $\mathrm{A}$ & $\mathrm{T}$ \\
\hline $\mathrm{C}^{-}$ & - & - & - & - & - & - & - & - & - \\
\hline OB-169 & Enterobacter cloacae & $382.5 \pm 2.1$ & 1.4 & - & + & - & - & + & - \\
\hline EB-14 & Enterobacter cloacae & $337.6 \pm 0.7$ & 1.6 & - & + & - & - & + & - \\
\hline EB-15 & Pantoea agglomerans & $321.9 \pm 4.3$ & 1.9 & - & + & - & - & + & - \\
\hline EB-21 & Yersinia intermedia & $316.9 \pm 3.3$ & 2.7 & - & + & - & - & + & - \\
\hline HB-234 & Enterobacter cloacae & $304.4 \pm 2.5$ & 1.8 & - & + & - & - & + & - \\
\hline HB-230 & Enterobacter cloacae & $298.7 \pm 2.3$ & 2.1 & - & + & - & - & + & - \\
\hline HB-207 & Bacillus subtilis & $295.8 \pm 3.7$ & 1.7 & + & - & - & - & + & - \\
\hline HB-204 & Enterobacter cloacae & $282.1 \pm 3.2$ & 1.7 & - & + & - & - & + & - \\
\hline HB-228 & Bacillus pumilis & $281.3 \pm 2.8$ & 1.6 & + & - & - & - & + & - \\
\hline AZB-64 & Lysinibacillus sphaericus & $278.8 \pm 7.3$ & 1.9 & + & - & - & - & + & - \\
\hline ZEB-94 & Enterobacter cloacae & $259.4 \pm 7.9$ & 5.1 & - & + & - & - & + & - \\
\hline EB-38 & Enterobacter cloacae & $265.5 \pm 4.9$ & 4.8 & - & + & - & - & + & - \\
\hline MK-252 & Bacillus subtilis & $243.8 \pm 3.0$ & 4.5 & + & - & - & - & + & - \\
\hline İB-162 & Bacillus atrophaeus & $258.8 \pm 4.7$ & 1.4 & + & - & - & - & + & - \\
\hline MK-262 & Bacillus atrophaeus & $247.8 \pm 2.5$ & 1.9 & + & - & - & - & + & - \\
\hline
\end{tabular}

C: control (pure water), PGPR:Plant growth promoting rhizobacteria, NBRIP: National Botanical Research Institute's phosphate growth mediums :phosphates solubilizing index, LOPAT: Levan, Oxidase, Potato soft-rot, Arginine dehydrolase, Tobacco hypersensitivity

\section{Effect of PSB on Onion Growth}

\section{Onion plant height}

Pot tests were performed to determine the effects of $\mathrm{P}$ solubilizing strains on onion plant growth. Plant height ranged from 16.3 to $26.1 \mathrm{~cm}$. Among tested strains, nine PSB (EB-14, OB-169, EB-15, İ-162, MK252, HB-204, HB-234, MK-262 and HB-228) significantly stimulated plant growth of 14.8 to $38.8 \%$ in comparison to the control experiment. In contrast, five strains (AZB-64, HB-207, ZEB-94, EB-38, EB-21) showed reducing plant height, it was not statistically significant according to the control. The stimulation of plant height was statistically observed, with EB-14, OB-169 and EB-15 higher in comparison to ISR 2000 (Table 2).

\section{Number of onion leaves}

The inoculation of seeds with PSB also affected the number of onion plant leaves. The onion leaves ranged from 2.3 to $4.8 \mathrm{~cm}$. Onion leaves were stimulated 3 to $70 \%$. The application of AZB-64 reduced onion leaf numbers by $2.3 \%$, but this application did not differ significantly according to the negative control. Among the PSB, three strains: EB-1, OB-169 and EB-15 were found to be more statistically significant (50 to 70\%) than other bacterial strains and the negative control with regard to the growth in numbers of leaves. Moreover, the EB-14 and OB-169 strains significantly affected the number of leaves compared to ISR 2000 $(p \leq 0.05)$ (Table 2).

\section{Onion bulb diameter}

The diameters of the onion bulbs was also affected by PSB inoculation. Onion bulb diameter ranged from 3.1 to $5.1 \mathrm{~cm}$. All strains stimulated onion bulb growth by 6.4 to $64.5 \%$ compared to the growth of a noninoculated control bulb. Eleven PSB strains (EB-14, OB-169, EB-15, İ-162, MK-252, HB-204, HB-234, MK-262, HB-228, HB-230, EB-21) significantly increased onion diameter compared to the to negative control by 25.8 to $64.5 \%$. Additionally, six strains (EB14, OB-169, EB-15, İ-162, MK-252 and HB-204) significantly stimulated onion bulb growth (45.1 to $64.5 \%)$ compared to ISR $2000(\mathrm{p} \leq 0.05)$ (Table 2$)$.

\section{Average root length}

All PSB strains increased the onion root length compared to the negative control inoculation. The average onion root length ranged from 3.8 to $5.5 \mathrm{~cm}$. Root length was statistically affected by six strains (EB-14, OB-169, EB-15, İ-162, MK-252, HB-204) in comparison to the negative control, whereas other PSB treatments did not show a significant increase. However, the strains EB-14, OB-169, MK-252 and EB15 showed significant increases of 36.8 to $44.7 \%$ over inoculation with ISR $2000(\mathrm{p} \leq 0.05)$ (Table 2). 
Table 2.The effect of phosphate solubilizing PGPR strains on onion growth Çizelge 2. Fosfat çözücü PGPR izolatlarının soğan gelişimi üzerine etkisi

\begin{tabular}{|c|c|c|c|c|c|c|}
\hline $\begin{array}{c}\text { Treatment } \\
\text { (Uygulamalar) }\end{array}$ & $\begin{array}{l}\text { Plant height } \\
\text { (Bitki yüksekliği) } \\
\text { (cm) } \pm \text { SD }\end{array}$ & $\begin{array}{c}\text { Effect } \\
\text { (Etki) } \\
\%\end{array}$ & $\begin{array}{c}\text { Number } \\
\text { leaves } \\
\text { (Yaprak } \\
\text { sayısI) } \pm \mathrm{SD}\end{array}$ & $\begin{array}{c}\text { Effect } \\
\text { (Etki) } \\
\%\end{array}$ & $\begin{array}{c}\text { Bulb } \\
\text { diameter } \\
(\text { Yumu çapı) } \\
(\mathrm{cm}) \pm \mathrm{SD}\end{array}$ & $\begin{array}{c}\text { Effect } \\
\text { (Etki) } \\
\%\end{array}$ \\
\hline C(Negative control) & $18.8 \pm 2.1^{\mathrm{de}}$ & - & $3 \pm 0.8^{\mathrm{de}}$ & - & $3.1 \pm 0.14^{\mathrm{g}}$ & - \\
\hline ISR 2000(Positive control) & $22.5 \pm 2.7 \mathrm{bc}$ & 19.6 & $4 \pm 0.6^{\mathrm{abcd}}$ & 33.3 & $3.9 \pm 0.3 \mathrm{e}$ & 25.8 \\
\hline Enterobacter cloacae EB-14 & $26.1 \pm 2.4^{\mathrm{a}}$ & 38.8 & $4.8 \pm 0.4^{\mathrm{ab}}$ & 60 & $5.1 \pm 0.3^{\mathrm{a}}$ & 64.5 \\
\hline Enterobacter cloacae OB-169 & $26 \pm 1.7 \mathrm{a}$ & 38.2 & $5.1 \pm 0.7 \mathrm{a}$ & 70 & $5.0 \pm 0.8^{\mathrm{abc}}$ & 61.2 \\
\hline Pantoea agglomerans EB-15 & $25.5 \pm 2.1^{\mathrm{a}}$ & 35.6 & $4.5 \pm 0.8^{\mathrm{abc}}$ & 50 & $5.0 \pm 0.7 \mathrm{ab}$ & 61.2 \\
\hline Bacillus atrophaeus IB-162 & $24.6 \pm 1.9^{\mathrm{ab}}$ & 25 & $4.3 \pm 1.3^{\mathrm{abcd}}$ & 43.3 & $4.5 \pm 0.4^{\mathrm{cd}}$ & 45.1 \\
\hline Bacillus subtilis MK-252 & $22.6 \pm 4.1^{\mathrm{bc}}$ & 20.2 & $4 \pm 1.09^{\mathrm{abcd}}$ & 33.3 & $4.5 \pm 0.4^{\mathrm{cd}}$ & 45.1 \\
\hline Enterobacter cloacae $H B-204$ & $22.3 \pm 1.8^{\mathrm{bc}}$ & 18.6 & $3.5 \pm 1.0^{\text {bcde }}$ & 16.6 & $4.5 \pm 0.5^{\mathrm{cd}}$ & 45.1 \\
\hline Enterobacter cloacae $H B-234$ & $22.1 \pm 2.4^{\mathrm{bc}}$ & 17.5 & $3.3 \pm 1.2^{\text {cde }}$ & 10 & $4.0 \pm 0.3^{\mathrm{de}}$ & 29 \\
\hline Bacillus atrophaeus MK-262 & $21.8 \pm 1.7^{\mathrm{bc}}$ & 15.9 & $4.1 \pm 1.4^{\mathrm{abcd}}$ & 36.6 & $4.0 \pm 0.4^{\mathrm{de}}$ & 29 \\
\hline Bacillus pumilis $H B-228$ & $21.6 \pm 2.0^{c}$ & 14.8 & $3.1 \pm 0.7$ cde & 3 & $3.9 \pm 0.3 \mathrm{e}$ & 25.8 \\
\hline Enterobacter cloacae $H B-230$ & $21 \pm 1.7^{\mathrm{de}}$ & 11.7 & $4.1 \pm 1.8^{\mathrm{abcd}}$ & 36.6 & $3.8 \pm 0.4^{\mathrm{ef}}$ & 22.5 \\
\hline Yersinia intermedia $E B-21$ & $18.6 \pm 1.7^{\mathrm{de}}$ & -1 & $3.5 \pm 0.5^{\text {bcde }}$ & 16.6 & $3.7 \pm 0.2^{\text {ef }}$ & 19.3 \\
\hline Enterobacter cloacae EB-38 & $16.8 \pm 2.1^{\mathrm{e}}$ & -10.6 & $3.3 \pm 1.2^{\text {cde }}$ & 10 & $3.7 \pm 0.4^{\mathrm{efg}}$ & 19.3 \\
\hline Enterobacter cloacae ZEB-94 & $16.8 \pm 1.8^{\mathrm{e}}$ & -10.6 & $3.1 \pm 0.8^{\text {de }}$ & 3 & $3.5 \pm 0.2^{\mathrm{efg}}$ & 12.9 \\
\hline Enterobacter cloacae $\mathrm{HB}-207$ & $16.6 \pm 2.0^{\mathrm{e}}$ & -11.7 & $3.6 \pm 1.5^{\text {bcde }}$ & 20 & $3.3 \pm 0.3^{\mathrm{fg}}$ & 6.4 \\
\hline Lysinibacillus sphaericus $A Z B-64$ & $16.3 \pm 1.8^{\mathrm{e}}$ & -13.2 & $2.3 \pm 0.5^{\mathrm{e}}$ & -23.3 & $3.3 \pm 0.3^{\mathrm{fg}}$ & 6.4 \\
\hline $\begin{array}{c}\text { Treatment } \\
\text { (Uygulamalar) }\end{array}$ & $\begin{array}{l}\text { Average Root } \\
\text { length } \\
\text { (Kök uzunluğu) } \\
\text { (cm) } \pm \mathrm{SD}\end{array}$ & $\begin{array}{c}\text { Effect } \\
(\text { Etki) } \\
\%\end{array}$ & $\begin{array}{l}\text { Bulb wet } \\
\text { weight } \\
\text { (Yumru yas } \\
\text { ăğgrlı̆ } \\
\text { (g) } \pm \text { SD } \\
\end{array}$ & $\begin{array}{c}\text { Effect } \\
(\text { Etki) } \\
\%\end{array}$ & $\begin{array}{l}\text { Bulb dry weight } \\
\text { (Yumru kuru } \\
\left.\text { a } \breve{g}_{1 r l} \breve{g_{I}}\right) \\
\text { (g) } \pm \text { SD }\end{array}$ & $\begin{array}{c}\text { Effect } \\
\text { (Etki) } \\
\%\end{array}$ \\
\hline C(Negative control) & $3.8 \pm 0.3^{\mathrm{e}}$ & - & $17 \pm 1.5^{\mathrm{e}}$ & - & $12.8 \pm 0.7^{\mathrm{e}}$ & - \\
\hline ISR 2000(Positive control) & $4.5 \pm 0.4^{\mathrm{cd}}$ & 18.4 & $19.1 \pm 0.9^{\mathrm{cd}}$ & 12.3 & $15.1 \pm 0.7^{\mathrm{cd}}$ & 17.9 \\
\hline Enterobacter cloacae EB-14 & $5.1 \pm 0.6^{\mathrm{ab}}$ & 34 & $22.8 \pm 1.4^{\mathrm{a}}$ & 34.1 & $17.6 \pm 1.3^{\mathrm{ab}}$ & 37.5 \\
\hline Enterobacter cloacae OB-169 & $5.3 \pm 0.4^{\mathrm{ab}}$ & 39.4 & $22.3 \pm 2.5^{\mathrm{a}}$ & 31.1 & $18 \pm 1.6^{\mathrm{a}}$ & 40.6 \\
\hline Pantoea agglomerans EB-15 & $5.5 \pm 0.4^{\mathrm{a}}$ & 44.7 & $22.1 \pm 1.1^{\mathrm{a}}$ & 30 & $17.6 \pm 1.3^{\mathrm{ab}}$ & 37.5 \\
\hline Bacillus atrophaeus IB-162 & $4.9 \pm 0.4^{\mathrm{bc}}$ & 28.9 & $21.1 \pm 1.6^{\mathrm{ab}}$ & 27 & $17 \pm 1.4^{\mathrm{abc}}$ & 32.8 \\
\hline Bacillus subtilis MK-252 & $5.2 \pm 0.2^{\mathrm{ab}}$ & 36.8 & $21.3 \pm 1.2^{\mathrm{ab}}$ & 25.2 & $17 \pm 1.9 \mathrm{abc}$ & 32.8 \\
\hline Enterobacter cloacae $H B-204$ & $4.8 \pm 0.5^{\mathrm{bc}}$ & 26.3 & $21.3 \pm 1.0^{\mathrm{ab}}$ & 25.2 & $17.8 \pm 1.3^{\mathrm{a}}$ & 39 \\
\hline Enterobacter cloacae $H B-234$ & $4.2 \pm 0.2^{\mathrm{de}}$ & 10.5 & $20 \pm 1.7^{\mathrm{bc}}$ & 17.6 & $15.6 \pm 2^{\mathrm{bcd}}$ & 21.8 \\
\hline Bacillus atrophaeus MK-262 & $4.4 \pm 0.4^{\mathrm{cd}}$ & 15.7 & $19.8 \pm 0.7^{\mathrm{bc}}$ & 16.4 & $15.5 \pm 1.6^{\mathrm{cd}}$ & 21 \\
\hline Bacillus pumilis $H B-228$ & $4.2 \pm 0.5^{\mathrm{de}}$ & 10.5 & $18.6 \pm 1.5^{\text {cde }}$ & 9.4 & $14.6 \pm 1.7^{\mathrm{de}}$ & 14 \\
\hline Enterobacter cloacae $H B-230$ & $4.2 \pm 0.4^{\mathrm{de}}$ & 10.5 & $18.3 \pm 1.7^{\text {cde }}$ & 7.6 & $13.5 \pm 2^{\mathrm{de}}$ & 5.4 \\
\hline Yersinia intermedia $E B-21$ & $4.1 \pm 0.4^{\mathrm{de}}$ & 7.8 & $18.1 \pm 1.1^{\text {cde }}$ & 6.4 & $13.5 \pm 1.3^{\text {de }}$ & 5.4 \\
\hline Enterobacter cloacae $E B-38$ & $4.2 \pm 0.2^{\mathrm{de}}$ & 10.5 & $18 \pm 1.7^{\text {cde }}$ & 5.8 & $14.6 \pm 1^{\mathrm{de}}$ & 14 \\
\hline Enterobacter cloacae ZEB-94 & $3.9 \pm 0.3^{\mathrm{e}}$ & 2.6 & $17.6 \pm 1.9^{\mathrm{de}}$ & 3.5 & $13 \pm 2^{\mathrm{e}}$ & 1.5 \\
\hline Enterobacter cloacae $\mathrm{HB}-207$ & $4 \pm 0.2^{\mathrm{de}}$ & 5.2 & $17.6 \pm 2.2^{\mathrm{de}}$ & 3.5 & $14.1 \pm 1.6^{\mathrm{de}}$ & 10.1 \\
\hline Lysinibacillus sphaericus $A Z B-64$ & $3.9 \pm 0.4^{\mathrm{e}}$ & 2.6 & $17.5 \pm 1.8^{\mathrm{de}}$ & 2.9 & $12.8 \pm 2.4^{\mathrm{e}}$ & 0 \\
\hline
\end{tabular}

C: seeds infested with water ,ISR 2000: Lactobacillus acidophilus + yeast extract + plant extract + benzoic acid (Improcrop). Values are means of five replicates, Mean values (mean \pm Standard Deviation) sharing the same letter do not differ significantly by Duncan's Multiple Range Test at $\mathrm{p} \leq 0.05$.

\section{Bulb fresh and dry weight}

Onions inoculated with PSB strains increased the fresh and dry weight of their bulbs at different rates. The eight PSB strains (EB-14, OB-169, EB-15, IB-162, MK-252, HB-204, HB-234 and MK-262) significantly increased the growth in the fresh and dry weights of the bulb by 16.4 to $34.1 \%$ compared to the noninoculated control plant. When the growth results were compared with the ISR 2000, six strains (EB-14, OB169, EB-15, IB-162, MK-252 and HB-204) there was a significant increase in fresh weight, at the same time, strains EB-14, OB-169 and EB-15 significantly 
increased dry weight compared to ISR 2000 ( $\mathrm{p} \leq 0.05)$

growth is also given in Figure 2.

(Table 2). The effect of PSBs on all parameters on onion

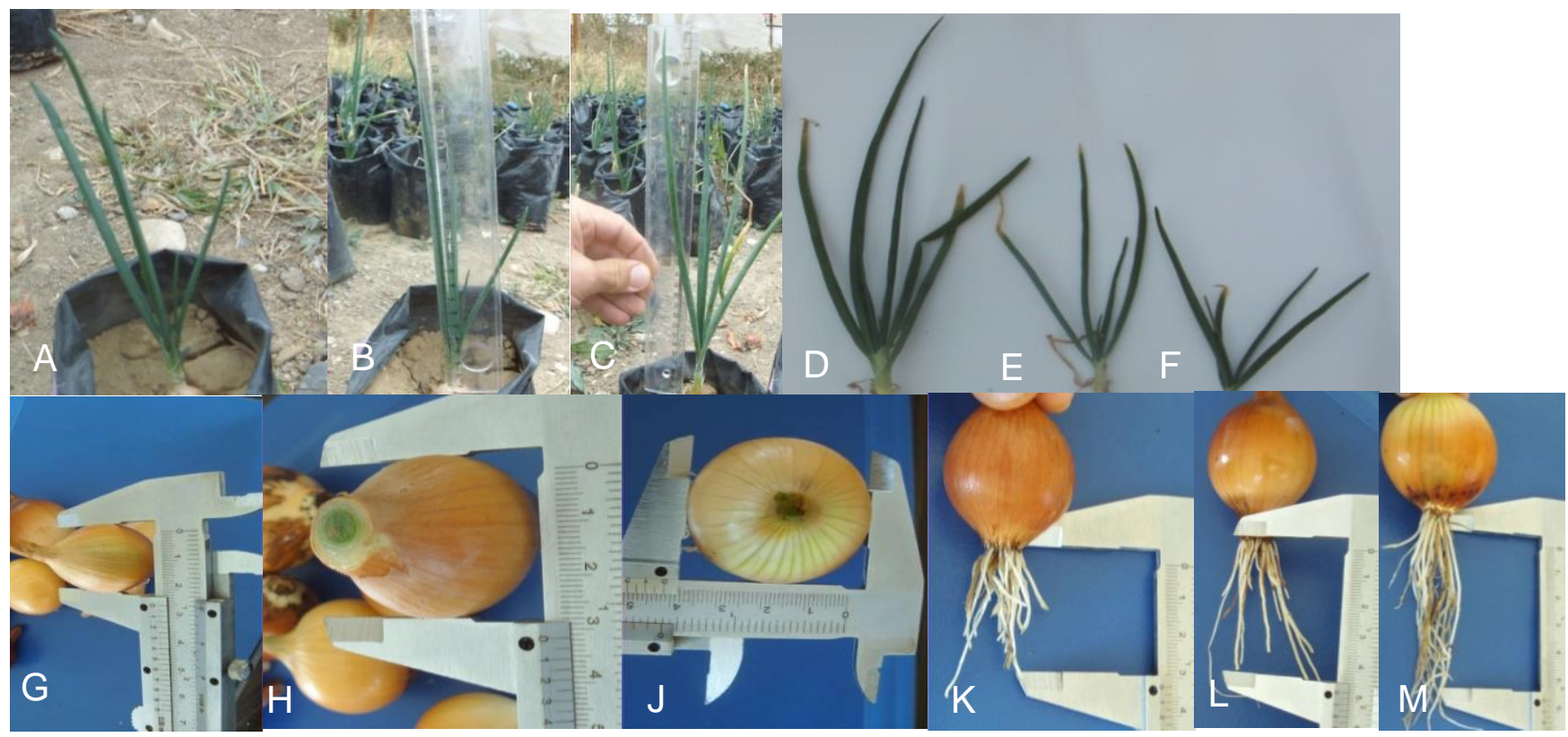

Figure 2. Influence of PSB strains (A:Negative control, B: Bacillus subtilis MK-252, C: Enterobacter cloacae (OB-169) on onion plant height performance. Influence of PSB strains (D: Enterobacter cloacae EB-14, E: Pantoea agglomerans EB-15, $\mathrm{F}$ :Negative control) on the number of onion plant leaves, Influence of PSB strains (G:Negative control, H: Bacillus subtilis $M K-252$, J:ISR 2000) on onion bulb diameter, Influence of PSB strains (K:Negative control, L: Bacillus pumilus $H B-228$, M: Pantoea agglomerans EB-15) on average onion root length

Shekil 2.PSB izolatların soğan bitki boyuna etkisi(A:Negatif kontrol, B: Bacillus subtilis MK-252, C: Enterobacter cloacae (OB169). PSB izolatların soğan yaprak sayısına etkisi((D: Enterobacter cloacae EB-14, E:Pantoea agglomerans EB-15, F:Negatif kontrol. PSB izolatların soğan yumru çapına etkisi(G:Negatif control, H: Bacillus subtilis MK-252, J:ISR 2000). PSB izolatların soğan kök uzunluğuna etkisi(K:Negative control, L: Bacillus pumilus HB-228, M: Pantoea agglomerans EB-15)

\section{DISCUSSION}

PSB colonize at the plant roots and shows useful effects on plant growth and development through a large diversity of methods. The specific mechanism by which PGPR induces plant growth is not clearly established, while different theories, such as the production of IAA, repression of destructive organisms, solubilization of phosphates and a rising mineral uptake are generally believed to be related (Ludueña et al., 2018). $\mathrm{P}$ is one of the important nutrients for plants. Most of the $\mathrm{P}$ in the soil is insoluble and cannot be used by the plants (Richardson, 2001). In this study, PSB strains were evaluated for their effects on onion growth. Phosphate solubilizing strains form a large zone on NBRIP agar medium. However, some of the strains did not produce large halo zones on an agar plate. This is possibly because of the diverse diffusion proportion of diverse organic acids secreted by the PSB. Therefore, the PSBs were also screened in NBRIP broth medium to calculate their phosphate solubilizing efficiency. Thus, the phosphate solubilizing feature of microorganisms were easily identified. Similar to the present study, it has also been reported that phosphate solubilization of microorganisms are different for isolated and distinct locations. Recently endophytic and epiphytic plant growth promoting bacteria (PGPB) were isolated from healthy almond trees and plant growth promoting mechanisms were characterized. By using MALDI-TOF analyses, 19 Gram-negative isolates, belonging to Serratia, Pseudomonas, Ochrobactrum and Enterobacter genus and 26 Grampositive isolates, belonging to Bacillus and Arthrobacter genus were identified (Aktan and Soylu, 2020). In their study, 46 isolates were positive for siderophore production, 45 isolates for ammonium production, 35 isolates solubilized phosphorus varying ratios, and all isolates produced IAA. For the study were used solid and liquid medium, and the phosphate solubilizing ability of microorganisms were detected in a range from 80 to $100 \mathrm{ppm}$ (Audipudi et al., 2012). In another study, the isolation of PSB was done using Pikovskaya's agar. In this study, thirty-two strains were inoculated on Pikovskaya's agar plates to evaluate the $\mathrm{P}$ solubilization index (PSI). Researchers calculated the SI of PSB strains ranging from 1.8 to 5.0 (Alia et al., 2013). The beneficial effect of PSBs in providing sufficient levels of mineral nutrients, particularly $\mathrm{P}$, in crop production has been formally reported. Verma et al. (2015), reported on the PSB Enterobacter, Pantoea, Azotobacter, Burkholderia, 
Citrobacter, Pseudomonas and Bacillus in wheat. There have been investigations of bacteria belonging to genus Bacillus, Enterobacter, Pseudomonas, Serratia that solubilize the otherwise insoluble $\mathrm{P}$ compounds and increase plant growth (Hameeda et al., 2008; Duman and Soylu, 2019). They observed that five inoculated bacterial strains with PSB and other PGPR traits increased the plant biomass by 20 to $40 \%$ under greenhouse conditions. Suri and Choudhary (2013), state that application of PSB improved the productivity, protein content, and nutrient uptake in soybean (Glycine max).Telek et al.(2019), also reported the effects of rhizobacteria were found favorable on such characteristics as fruit seeds fresh weight, fruit seeds dry weight, and fruit flesh fresh weight, fruit flesh dry weight, fruits wet weight and root length. Biswas et al. (2018), showed that the PSB strains Bacillus megaterium (MF589715), Staphylococcus haemolyticus (MF 589716) and Bacillus licheniformis (MF 589720) sterilized seeds of mung beans (Vigna radiata), and indicated a greater germination ratio and a higher growth under bacterium-enriched conditions. Duman and Soylu (2019) recently conducted a study for determination of plant growth-promoting traits (such as IAA, phosphate solubilization) and antagonistic potentials (such as siderophore and ammonia productions) of endophytic plant growthpromoting bacteria (PGPB) from healthy bean plants growing in different regions of Turkey against bacterial halo blight disease agent Pseudomonas syringae pv. phaseoli in vitro conditions. Among the tested antagonist bacterial isolates, 10 isolates were positive for the production of a-amylase, 7 isolates positive for phosphate solubilization, 29 isolates positive for siderophore production, 11 isolates positive for protease production. Among the bacterial isolates, Acinetobacter calcoaceticus produced a relatively large amount of phosphatase by forming inhibition zones. The increasing growth of onion caused by PSB found in this study is in agreement with the findings of Gupta et al., (2012). In their work, they investigated the effect of four PSB on the growth of Aloe barbadensis in soil containing tricalcium phosphate (TCP). Researchers determined that the PSB: Serratia marcescens, Enterobacter hormaechei, Burkholderia gladioli and Pseudomonas synxantha, increased $\mathrm{P}$ solubilization by 25 to $340 \mathrm{ppm}$ in the liquid medium. Inoculation of PSB increased leaf length by $39.5 \%$, root length by $31.1 \%$ and the total number of leaves by $48.1 \%$ in comparison to the control plants. In this research, PSB strains were found to be effective solubilizers of phosphates. The ability of PSB strains to solubilize otherwise insoluble $\mathrm{P}$ and convert it to a form available to plant is an important characteristic under conditions where $\mathrm{P}$ is a limiting factor for plant growth (Zhang et al., 2012). Due to high antagonistic properties, efficient isolates of Bacillus spp. may be used as biocontrol agent against soilborne diseases as an alternative to pesticides to promote organic and sustainable agriculture (Soylu et al., 2020).

\section{CONCLUSION}

The study results clearly demonstrated the potential of $\mathrm{P}$ solubilizers on onion plant growth. However, further research is needed to understand the specific mechanisms involved in the positive effects of PSB on onion growth under field conditions.

\section{ACKNOWLEDGMENTS}

This research was supported by the project's financial support of Kahramanmaras Sutcu Imam University Scientific Research Projects (grant no. 2014/3-28 D) is gratefully acknowledged. Ph.D. thesis of İdris BEKTAŞ is partially used to produce this manuscript.

\section{Statement of Conflict of Interest and Author's Contributions}

Authors have declared no conflict of interest.

\section{Author's Contributions}

The contribution of the authors is equal.

\section{REFERENCES}

Aktan ZC, Soylu S 2020. Diyarbakir Ilinde Yetişen Badem Ağaçlarindan Endofit ve Epifit Bakteri Türlerinin Izolasyonu ve Bitki Gelişimini Teşvik Eden Mekanizmalarinin Karakterizasyonu. KSÜ Tarım ve Doğa Dergisi 23(3): 641-654.

Alia AA, Shahida N, Bushra J, Saeed A 2013. Phosphate Solubilizing Bacteria Associated with Vegetables Roots in Different Ecologies. Pak J Bot 45: 535-544.

Aktan ZC, Soylu S 2020. Diyarbakır İlinde Yetişen Badem Ağaçlarından Endofit ve Epifit Bakteri Türlerinin İzolasyonu ve Bitki Gelişimini Teşvik Eden Mekanizmalarının Karakterizasyonu. KSÜ Tarım ve Doğa Derg 23(3): 641-654.

Audipudi AV, Kumar NP, Sudhir A 2012. Phosphate Solubilizing Microorganisms Associated with Chollangi Mangrove Soil in East Coast of India. International Journal of Scientific \& Engineering Research 3(11): 2229-5518.

Barton CJ 1948. Photometric Analysis of Phosphate Rock. Analytical Chemistry 20(11): 1068-1073.

Bhat SA, Singh J, Vig AP 2017. Earthworms as Organic Waste Managers and Biofertilizer Producers. Waste and Biomass Valorization 9(7): 1073-1086.

Biswas JK, Banerjee, A, Rai M, Naidu R, Biswas B, Vithanage M, Dash MC, Sarkar SK, Meers E 2018. Potential Application of Selected Metal Resistant Phosphate Solubilizing Bacteria Isolated from the Gut of Earthworm (Metaphire Posthuma) in Plant 
Growth Promotion. Geoderma 330: 117-124.

Cruz-Paredes C, López-García Á, Rubæk GH, Hovmand MF, Sørensen P, Kjøller R 2017. Risk Assessment of Replacing Conventional P Fertilizers with Biomass Ash: Residual Effects on Plant Yield, Nutrition, Cadmium Accumulation and Mycorrhizal Status. Science of the Total Environment 575: 1168-1176.

Duman K, Soylu S 2019. Characterization of Plant Growth-Promoting Traits and Antagonistic Potentials of Endophytic Bacteria from Bean Plants Against Pseudomonas syringae pv. phaseolicola. Bitki Koruma Bülteni 59(3): 59-69.

Gupta M, Kiran S, Gulati A, Singh B, Tewari R 2012. Isolation and Identification of Phosphate Solubilizing Bacteria able to Enhance the Growth and Aloin-A Biosynthesis of Aloe Barbadensis Miller. Microbiological Research 167(6): 358-363.

Dadaşoğlu F, Kotan R 2017. Bazı Sebze ve Meyvelerde Yumuşak Çürüklük Oluşturan Pektolitik Bakterilerin Tanı ve Karakterizasyonu. Iğdır Üniversitesi Fen Bilimleri Enstitüsü Dergisi, 7(1): $155-161$.

Hameeda B, Harini G, Rupela O, Wani S, Reddy G 2008. Growth Promotion of Maize by PhosphateSolubilizing Bacteria Isolated from Composts and Macrofauna. Microbiological Research 163(2): 234242.

Khan MS, Zaidi A, Ahemad M, Oves M, Wani PA 2010. Plant Growth Promotion by Phosphate Solubilizing Fungi-Current Perspective. Archives of Agronomy and Soil Science 56(1): 73-98.

Kumar A, Maurya B, Raghuwanshi R 2014. Isolation and Characterization of PGPR and their Effect on Growth, Yield and Nutrient Content In Wheat (Triticum aestivum L.).Biocatalysis and Agricultural Biotechnology 3(4): 121-128.

Kumar A, Singh R, Chhillar R 2001. Influence of Nitrogen and Potassium Application on Growth, Yield and Nutrient Uptake by Onion (Allium cepa). Indian Journal of Agronomy 46(4): 742-746.

Lompo F, Bationo A, Sedogo MP, Bado VB, Hien V, Ouattara B 2018. Role of Local Agro-minerals in Mineral Fertilizer Recommandations for Crops: Examples of Some West Africa Phosphate Rocks, Improving the Profitability, Sustainability and Efficiency of Nutrients Through Site Specific Fertilizer Recommendations in West Africa AgroEcosystems. Springer, pp. 157-180.

Ludueña LM, Anzuay MS, Angelini JG, McIntosh M, Becker A, Rupp O, Goesmann A, Blom J, Fabra A, Taurian T 2018. Strain Serratia sp. S119: A Potential Biofertilizer for Peanut and Maize and A Model Bacterium to Study Phosphate Solubilization Mechanisms. Applied Soil Ecology 126: 107-112.

Majeed A, Abbasi MK, Hameed S, Imran A, Rahim N 2015. Isolation and Characterization of Plant Growth-Promoting Rhizobacteria from Wheat
Rhizosphere and their Effect on Plant Growth Promotion. Frontiers in Microbiology 6: 198.

Moragrega C, Llorente I, Manceau C, Montesinos E 2003. Susceptibility of European Pear Cultivars to Pseudomonas syringae pv. syringae using Immature Fruit and Detached Leaf Assays. European Journal of Plant Pathology 109(4): 319326.

Nasri S, Anoush M, Khatami N 2012. Evaluation of Analgesic and Anti-Inflammatory Effects of Fresh Onion Juice in Experimental Animals. African Journal of Pharmacy and Pharmacology 6(23): 1679-1684.

Nautiyal CS 1999. An Efficient Microbiological Growth Medium for Screening Phosphate Solubilizing Microorganisms. FEMS Microbiology Letters 170(1): 265270.

Premono ME, Moawad A, Vlek P 1996. Effect of Phosphate-Solubilizing Pseudomonas Putida on the Growth of Maize and its Survival in the Rhizosphere.( No. REP-12113. CIMMYT.)

Ramamoorthy V, Raguchander T, Samiyappan R 2002. Enhancing Resistance of Tomato and Hot Pepper to Pythium Diseases by Seed Treatment with Fluorescent Pseudomonads. European Journal of Plant Pathology 108(5): 429-441.

Richardson AE 2001. Prospects for using Soil Microorganisms to Improve the Acquisition of Phosphorus by Plants. Functional Plant Biology 28(9): 897-906.

Rodríguez H, Fraga R 1999. Phosphate Solubilizing Bacteria and their Role in Plant Growth Promotion. Biotechnology Advances 17(4-5): 319-339.

Schaad NW, Jones JB, Chun W 2001. Laboratory Guide for the Identification of Plant Pathogenic Bacteria. American Phytopathological Society (APS Press) 398 p.

Sharma SB, Sayyed RZ, Trivedi MH, Gobi TA 2013. Phosphate Solubilizing Microbes: Sustainable Approach for Managing Phosphorus Deficiency in Agricultural Soils. Springer Plus 2(1): 587.

Slimestad R, Fossen T, Vågen IM, 2007. Onions: a Source of Unique Dietary Flavonoids. Journal of Agricultural and Food Chemistry 55(25): 1006710080.

Soylu EM, Soylu S, Kara M, Kurt S 2020. Sebzelerde Sorun Olan Önemli Bitki Fungal Hastalık Etmenlerine Karşı Vermikomposttan İzole Edilen Mikrobiyomlarm in vitro Antagonistik Etkilerinin Belirlenmesi. KSÜ Tarım ve Doğa Dergisi 23(1): 718.

Suri V, Choudhary AK 2013.Glycine-GlomusPhosphate Solubilizing Bacteria Interactions Lead to Fertilizer Phosphorus Economy in Soybean in a Himalayan acid Alfisol.Communications in Soil Science and Plant Analysis 44(20): 3020-3029.

Telek Ü, Akıncı İE, Küsek M 2019. Rhizobakteri İzolatlarının Kırmızı Biberin (Capsicum annuum 
L.) Verim ve Bitkisel Özellikleri Üzerine Etkileri. KSÜ Tar Doğa Derg 22(1): 62-70.

Verma P, Yadav AN, Khannam KS, Panjiar N, Kumar S, Saxena AK, Suman A 2015. Assessment of Genetic Diversity and Plant Growth Promoting Attributes of Psychrotolerant Bacteria Allied with Wheat (Triticum Aestivum) from the Northern Hills Zone of India. Annals of Microbiology 65(4): 1885-1899.

Zhang J, Liu J, Meng L, Ma Z, Tang X, Cao Y, Sun L
2012. Isolation and Characterization of Plant Growth-Promoting Rhizobacteria from Wheat Roots by Wheat Germ Agglutinin Labeled with Fluorescein Isothiocyanate. The Journal of Microbiology 50(2): 191-198.

Zhang L, Feng G, Declerck S 2018. Signal Beyond Nutrient, Fructose, Exuded by an Arbuscular Mycorrhizal Fungus Triggers Phytate Mineralization by a Phosphate Solubilizing Bacterium. The ISME Journal12(10): 2339-2351. 